\title{
Flow cytometry detection of planktonic cells with polycyclic aromatic hydrocarbons sorbed to cell surfaces
}

\author{
Maria I. Cerezo ${ }^{\mathrm{a}, *}$, Matthew Linden ${ }^{\mathrm{b}}$, Susana Agustí ${ }^{\mathrm{a}, \mathrm{c}}$ \\ a Department of Global Change Research, IMEDEA (CSIC-UIB), Instituto Mediterráneo de Estudios Avanzados, Miquel Marqués 21, 07190 Esporles, Spain \\ ${ }^{b}$ Centre for Microscopy, Characterisation and Analysis (CMCA), The University of Western Australia, Mail Bag 510, 35 Stirling Highway, Crawley 6009, WA, Australia \\ ${ }^{\mathrm{c}}$ Red Sea Research Center, King Abdullah University of Science and Technology, Thuwal 23955-6900, Saudi Arabia
}

\section{A R T I C L E I N F O}

\section{Article history:}

Received 4 September 2016

Received in revised form 30 January 2017

Accepted 5 February 2017

Available online 17 February 2017

\section{Keywords:}

PAHs

Flow cytometry

Phytoplankton

Oil spills

Cell fluorescence

Ultraviolet laser

\begin{abstract}
A B S T R A C T
Polycyclic aromatic hydrocarbons are very important components of oil pollution. These pollutants tend to sorb to cell surfaces, exerting toxic effects on organisms. Our study developed a flow cytometric method for the detection of PAHs sorbed to phytoplankton by exploiting their spectral characteristics. We discriminated between cells with PAHs from cells free of PAHs. Clear discrimination was observed with flow cytometer provided with 375 or $405 \mathrm{~nm}$ lasers in addition to the standard $488 \mathrm{~nm}$ laser necessary to identify phytoplankton. Using this method, we measured the relationship between the percentages of phytoplankton organisms with PAHs, with the decrease in the growth rate. Moreover, the development of this method could be extended to facilitate the study of PAHs impact on cell cultures from a large variety of organisms.
\end{abstract}

(c) 2017 Elsevier Ltd. All rights reserved.

\section{Introduction}

Polycyclic aromatic hydrocarbons (PAHs) are a subset of persistent organic pollutants in crude oil, refining oil and coal (McGrath et al., 2007). Oil spills, ship traffic and atmospheric transport are the major sources of PAHs pollution to the oceans (Neff, 1985). PAHs are toxic for organisms and show a strong hydrophobic sorption affinity for particulate surfaces (Gelboin, 1980; Lehr and Jerina, 1977; Meador et al., 1995). PAHs have low water solubility and tend to accumulate in planktonic organisms when deposited in oceans and lakes (Dachs et al., 2002; Fordham et al., 1985). When are sorbed and accumulated on the cell surface of phytoplanktonic organisms, PAHs enter slowly into the cells by a diffusive process (Fan and Reinfelder, 2003). The intracellular concentration of pollutant increases with time while the concentration in the cell membrane decreases (Fan and Reinfelder, 2003). Once sorbed to cells, PAHs interfere with plasma membranes (Neff, 1979), being able to seriously damage the DNA (Gelboin, 1980), and alter cell processes such as growth or photosynthesis (Singh and Gaur, 1988). These pollutants emit fluorescence when are excited by ultraviolet (UV) light (Dartnell et al., 2012; Suzuki et al., 2009). Pyrene and phenanthrene have peak excitation wavelengths between 355 and $405 \mathrm{~nm}$, and emission wavelengths from 400 to $500 \mathrm{~nm}$ (Fig. S1). This property

\footnotetext{
* Corresponding author.

E-mail addresses: mbel.cerezo@gmail.com (M.I. Cerezo), matthew.linden@uwa.edu.au (M. Linden), sagusti@imedea.uib-csic.es (S. Agustí).
}

has been used to detect PAHs in environmental samples by different techniques, such as high-performance liquid chromatography (HPLC) and fluorescence spectrometry. This method allows the determination of PAHs concentrations in waters samples with good sensitivity, which detection limit is between 0.34 and $14.11 \mathrm{ng} \mathrm{mL}^{-1}$ (Habibi and Hadjmohammadi, 2008).

Due to their fluorescent properties, we hypothesized that PAHs could be detected when are sorbed to particles and cell surfaces using a microscope or in a flow cytometer with a UV laser source. Epifluorescence microscopy, with UV illumination, was recently used to visualize crude oil droplets inside the digestive tract of different marine organisms such as copepods (Almeda et al., 2014a), heterotrophic dinoflagellates (Almeda et al., 2014b), Barnacle nauplii and Tornaria larvae (Almeda et al., 2014c). Also, the same technique was successful to observe the presence of crude oil in the fecal pellets of copepods (Almeda et al., 2014a). Fluorescent microscopy and flow cytometry techniques, are now broadly used in aquatic sciences to identify and quantify the cell abundance of phytoplankton and bacteria. Both techniques provide a single-cell analysis, but fluorescence microscopy is well suited to the resolution of morphological analysis (Muratori et al., 2008), and to follow kinetic and trophic responses in single cells (Godfrey et al., 2005). Flow cytometry allows fast automated cell counting as well as simultaneous multiparametric analysis of different cellular properties such as cell size and pigments auto-fluorescence (Marie et al., 2000), cell viability (Agustí and Sánchez, 2002), DNA content and cell cycle (Marie et al., 1997), and enzymatic and 
immunological responses, among a large variety of cellular properties after the appropriate staining of cells (Shapiro, 2005). Moreover, the flow cytometers allow the identification the tiny Prochlorococcus sp. populations, the most abundant photosynthetic organism in the open ocean (Chisholm et al., 1998), which cell fluorescence is too dim to be discriminated by epifluorescence microcopy. Flow cytometry techniques are used for a variety of studies, including toxicological tests (Czechowska and Van der Meer, 2011), and the analysis of the pollutants effects in aquatic environments (Echeveste et al., 2010, 2011; Hjorth et al., 2007). New generation multi-laser flow cytometers include a variety of excitation wavelengths, including those in the blue, violet and ultraviolet band, and a variety of wavelengths for emission filters increasing the detection of different cellular properties by multiplying the simultaneous fluorescent signals. Multi-laser flow cytometers are therefore a useful tool to discriminate planktonic cells from other particles. Phytoplankton has been very well identified by natural red fluorescence (emission $>610 \mathrm{~nm}$ when excited with blue light), due to the presence of chlorophyll a (Chlla) (Yentsch and Yentsch, 1979). In this study we propose that flow cytometers, implemented with a combination of blue and UV lasers, could allow the detection of PAHs sorbed to phytoplankton or other planktonic organisms.

The goal of our study was to assess whether phytoplanktonic cells with PAHs sorbed can be discriminated from unbound phytoplankton cells by flow cytometry, and determine the corresponding effect of PAHs sorption on the growth rate. For this purpose, we exposed phytoplankton cultures to different concentrations of PAHs, and compared the efficiency of three cytometers with different excitation lasers (UV, near UV and violet) to detect phytoplankton cells with sorbed PAHs. The development of this technic could be very useful in field studies, and may be relevant to monitor the evolution of oil spills or petrol inputs, and the dispersion in addition to its consequences for the marine environment.

\section{Materials and methods}

\subsection{Experimental organisms and PAHs}

Cultures of two marine phytoplankton species: Tetraselmis suecica (CSIRO CS-187) and Dunaliella salina (CSIRO CS-353) were used. D. salina was used in microscopy experiments, while T. suecica was used in the flow cytometry analysis. Cultures were grown in sterile polycarbonate bottles at $20{ }^{\circ} \mathrm{C}$ under continuous $140 \mathrm{nMol}$ Photons $\mathrm{m}^{-2} \mathrm{~s}^{-1}$ light and nutrient-rich medium (f/2).

Concentrated solutions of pyrene and anthracene (Sigma Aldrich purity $>98 \%$ ), of $2 \times 10^{4} \mu \mathrm{g} \mathrm{mL}{ }^{-1}$ for pyrene and $10^{4} \mu \mathrm{g} \mathrm{mL}-1$ for anthracene, were prepared in acetone (ACS) as solvent. Both solutions were kept at $4{ }^{\circ} \mathrm{C}$ to avoid acetone evaporation.

\subsection{Approaches/techniques}

We used flow cytometry and epifluorescence microscopy to detect PAHs sorbed to phytoplankton.

\subsubsection{Epifluorescence microscopy}

An Olympus IX81 epifluorescence microscope, with a blue light filter (excitation wavelength 470-495, emission wavelength 510-550 nm, dichromatic $505 \mathrm{~nm}$ ), was used for the excitation of chlorophyll $a$ in D. Salina cultures. Hydrocarbons sorbed to cell surface in cultures treated with PAHs (pyrene and anthracene), or in untreated cultures, were analyzed using a UV filter cube (excitation wavelength $360-370 \mathrm{~nm}$, emission wavelength $420-460 \mathrm{~nm}$, dichromatic $400 \mathrm{~nm}$ ). Samples were observed at $\times 600$ magnification (Olympus PlanApo $60 \times$ NA1.4 oil immersion objective). A digital monochrome camera and the ImageJ $1.45 \mathrm{~s}$ software were used for the image analysis.

\subsubsection{Flow cytometry with UV}

Flow cytometry analyses were performed on three different instruments (BD Influx, BD FACSAria II, and BD FACSCanto II) in order to compare the different optical configurations for the measurement of cells with PAHs. All instruments were equipped with a $488 \mathrm{~nm}$ laser and phytoplankton was identified by characteristic $488 \mathrm{~nm}$ laser scatter and fluorescence emission in the 585/42 $\mathrm{nm}$ (accessory pigments) and $690 / 40 \mathrm{~nm}$ (Chlla) ranges. The appropriate excitation wavelength for pyrene and anthracene has been described between 320 and $340 \mathrm{~nm}$ and 320-360 nm, respectively (Basu et al., 2006; Dartnell et al., 2012; Suzuki et al., 2009), with emission spectra in the violet-blue range 360-430 nm (Dartnell et al., 2012; Suzuki et al., 2009). We therefore compared a common optical configuration for each cytometer with excitation between the UV and violet range. Analysis with the BD Influx ([355] 460/50 nm configuration: excitation laser of $355 \mathrm{~nm}$ and emission filter of 460/50 nm emission) and BD FACS Canto II ([405] 450/ $50 \mathrm{~nm}$ configuration: excitation laser of $405 \mathrm{~nm}$ and emission filter of $450 / 50 \mathrm{~nm}$ ) were performed at the Centre for Microscopy, Characterization and Analysis (CMCA; University of Western Australia, Perth), while analysis with the BD FACS Aria II ([375] 440/40 nm: excitation laser of $375 \mathrm{~nm}$ and emission filter of $440 / 40 \mathrm{~nm}$ ) were performed at the Mediterranean Institute of Advanced Studies (IMEDEA, CSIC, Spain).

Replicated samples $(0.5 \mathrm{~mL})$ from the different culture treatments, and from the controls, were analyzed. For the quantification of cell concentrations, an aliquot of a calibrated solution of fluorescent beads with $1 \mu \mathrm{m}$ diameter (Lot: 453,837; Polysciences Inc.) was included in each sample as an internal standard. Blank samples of filtered medium were measured after removing the cells using a $0.2 \mu \mathrm{m}$ pore size syringe filter system. Cultures growing with and without pyrene and anthracene were also analyzed to control residual fluorescence from the growth medium. The tests indicated no fluorescence noise signals from the medium that could have interfered with PAHs signals of phytoplankton cultures. The analysis of the cytograms acquired by flow cytometry was performed using FlowJo 9.4.4. and FACSdiva (Becton Dickinson) software.

\subsubsection{Experimental sets}

For conducting the experiments, the cultures were grown in triplicated bottles ( $2 \mathrm{~L}$ volume) until the start of the exponential growth phase. $200 \mathrm{~mL}$ of the cultures were aliquoted into sterile bottles containing pyrene or anthracene, to achieve final concentrations in the range from 0.5 to $10^{3} \mu \mathrm{g} \mathrm{L}^{-1}$ (as outlined in Table 1), and were incubated between 5 and 14 days. Before add the $200 \mathrm{~mL}$ of cultures into the treatment bottle, the acetone from pyrene and anthracene solutions was allowed to evaporate during $60 \mathrm{~min}$. Samples were driven for microscopic analysis every $48 \mathrm{~h}$, and for flow cytometer every $24 \mathrm{~h}$.

\subsubsection{Calculations}

The cultures growth rates $\left(\mu \mathrm{d}^{-1}\right)$ were calculated as the slope from the linear relationship between the natural logarithm of cells

Table 1

The different concentration ( $\mu \mathrm{L} \mathrm{L}^{-1}$ ) of pyrene and anthracene dosed to cultures of $T$. suecica during the flow cytometry experiments. The wavelengths correspond to the different lasers used for PAHs excitation, installed in the different flow cytometers used.

\begin{tabular}{|c|c|c|c|c|c|}
\hline \multicolumn{2}{|l|}{$405 \mathrm{~nm}$} & \multicolumn{2}{|l|}{$375 \mathrm{~nm}$} & \multicolumn{2}{|l|}{$355 \mathrm{~nm}$} \\
\hline Pyrene & Anthracene & Pyrene & Anthracene & Pyrene & Anthracene \\
\hline 0.5 & 0.5 & 2 & 0.5 & 0.5 & 10 \\
\hline 3.9 & 1.5 & 6 & 8 & 25 & 25 \\
\hline 7.8 & 3.1 & 25 & 25 & 50 & 50 \\
\hline 11.6 & 10 & 300 & 300 & 100 & 100 \\
\hline 25 & 25 & & & 300 & 500 \\
\hline 50 & 50 & & & 1000 & 1000 \\
\hline 100 & 100 & & & & \\
\hline 300 & 500 & & & & \\
\hline 1000 & 1000 & & & & \\
\hline
\end{tabular}


abundance and the incubation time (in days). The percentage of cells with PAHs, in each sample, was obtained as the fraction of the cell abundance with PAHs detected in the sample relative to the total abundance of cells in each sample. We used $t$-test and regression analysis (JMP program) to analyze the significance of the differences observed in the results obtained using the different flow cytometer configurations, and between growth rates and percentages of cells with PAHs sorbed.

\section{Results and discussion}

3.1. Detection of PAHs sorbed to phytoplankton cells by epifluorescencemicroscope

D. salina cells emitted red fluorescence from chlorophyll $a$ when were illuminated by blue light (470-495 nm; Fig. 1a) under microscope, and this emission was not affected by the incubation with PAHs. Control cells without PAHs did not show blue fluorescence emission when illuminated with UV-light filters (Fig. 1b). D. salina cells growing with pyrene emitted fluorescence in the wavelength range of the filter set wavelengths of $420-460 \mathrm{~nm}$ of the microscope when were excited by UV-light (360-370 nm excitation microscope filter), and this emission was not seen in control cells, in the absence of PAHs (Fig. 1). Conversely, blue emission from UV-excitation, was not observed in anthracene treated cells due to rapid photo bleaching (Fan and Reinfelder, 2003; Lehto et al., 2000; Nagata and Kondo, 1977; Roper, 2006). Rapid emission fading and degradation of PAHs under UV light has previously been raised as an issue, which may limit the applicability of the epifluorescence microscope for the analysis of PAHs sorbed to cells, in research examining micro-scale spatial distribution of PAHs in different soil samples (Roper, 2006). Moreover, analysis by microscopy requires tedious and labor-intensive individual counting of phytoplankton cells, making impractical the analysis of high number of samples.

\subsection{Cells with pyrene and anthracene detected by flow cytometry}

The mean fluorescence intensity (MFI) of blue emission increased in samples of T. suecica treated with pyrene or anthracene with all excitation wavelengths tested (Fig. 2). The greatest increase in MFI was observed with $355 \mathrm{~nm}$ laser excitation, while the least increase of MFI was observed after the excitation with the $405 \mathrm{~nm}$ laser (Fig. 2). Two distinct peaks of MFI were observed with both [405] 450/50 nm and [375] 440/40 nm configurations. These likely represent cells of $T$. suecica with PAHs accumulated on cell surface (bright peak) versus T. suecica cells without PAHs (dim peak). In the samples excited by the [375] $440 / 40 \mathrm{~nm}$ configuration, the bright subset of cells showed a 4-fold increase in peak MFI for pyrene and a 6-fold increase in anthracene treated samples over controls (Fig. 2). This was sufficient in order to gate and quantify the number of cells with accumulated PAHs (Fig. S2). A similar result was observed in samples excited by the [405] 450/50 nm configuration (Fig. 2); with bright subset MFI increased 4 and 12 fold over the dim subset for pyrene and anthracene respectively (Fig. 2; Fig. S2). However, differentiation of bright-blue and dim blue fluorescent cells was less reproducible when the [355] 460/50 nm was used, because the blue fluorescence increased highly for all cells (Fig. 2). This large increase in blue fluorescence with respect to the cells in the control, impeded a clear gating to identify and quantify the number of cells with accumulated PAHs (Fig. 2). The different flow cytometer's configuration showed differences in the detection of bright-blue fluorescent cells. When T. suecica was exposed to high dosages of anthracene, the percentages of cells with bright-blue fluorescence emission were significantly lower when the [355] 460/50 nm BD Influx configuration was used for the analysis (Table 2); although there were no significant differences between configurations when cells were exposed to low anthracene doses (Table 2). When $T$. suecica cells were exposed to low dosages of pyrene, the configuration of the [375] 440/40 nm BD FACS Aria II was more efficient for the excitation, helping to identify a significant larger percentage of cells with pyrene sorbed than the other two configurations (Table 2). Therefore, as the [355] 460/50 nm BD Influx showed more variable data that the other two laser configurations (Table 2), further experiments were performed using the [405] 450/ $50 \mathrm{~nm}$ BD FACS Canto II and the [375] 440/40 nm BD FACS Aria II configurations. Probably, the detection filter set of $460 \mathrm{~nm}$ of the Influx configuration was less sensitive for the detection of cells with anthracene. The emission spectra (Fig. S1) indicated a strong fall in the fluorescence emission at $460 \mathrm{~nm}$ for cells with anthracene, including those cells excited at $355 \mathrm{~nm}$.

The percentage of the bright subsets increased with the increasing pyrene and anthracene dose ( $p<0.0001$; Fig. 3 ), ranging from $3 \%$ to $10 \%$ respectively of total cells, to values of $100 \%$ for the highest PAHs dosages tested (Fig. 3). For dosages of pyrene lower than $50 \mu \mathrm{g} \mathrm{L}^{-1}$ nominal concentration, the percentage of the bright subset was lower when excited by the $405 \mathrm{~nm}$ laser than the $375 \mathrm{~nm}$ laser $(p<0.001)$. Conversely, when the pyrene dose exceeded $50 \mu \mathrm{g} \mathrm{L}-1$, there were not differences in the bright subset between two lasers. No such difference in the bright subset between lasers was observed with anthracene, regardless of dose. This reflects differences in the emission spectra of pyrene as was demonstrated by spectrofluorometry (Fig. S1), being differences in the fluorescence emission detected as a result of the laser used for the excitation. The fluorescence of cells with pollutant adsorbed, after the excitation by the $405 \mathrm{~nm}$ laser, showed lower values than those obtained when samples were excited by the $375 \mathrm{~nm}$ laser; these differences were statistically significant $(p<0.001)$.

A population with the characteristic bright blue fluorescence, representing accumulated PAHs, was already discernable at $1 \mathrm{~h}$ (Fig.
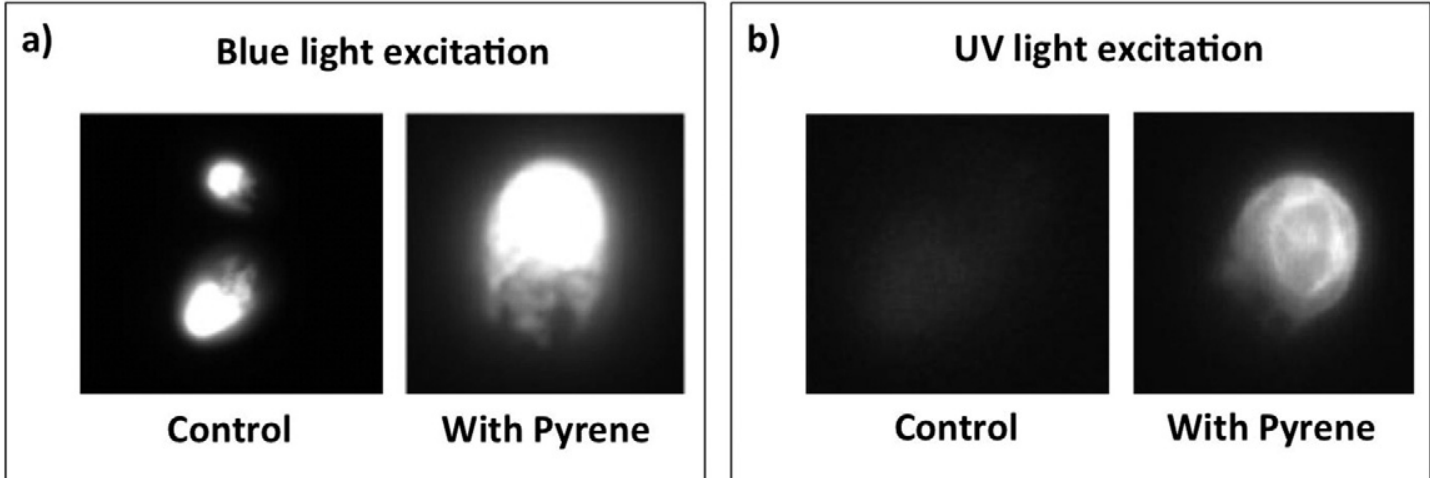

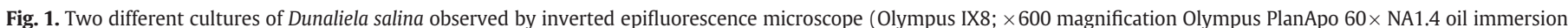

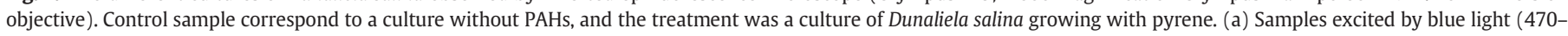

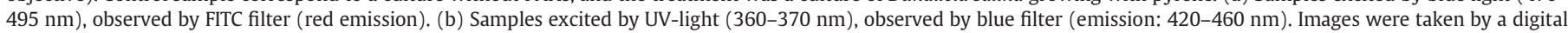
monochrome camera. 
$405 \mathrm{~nm}$

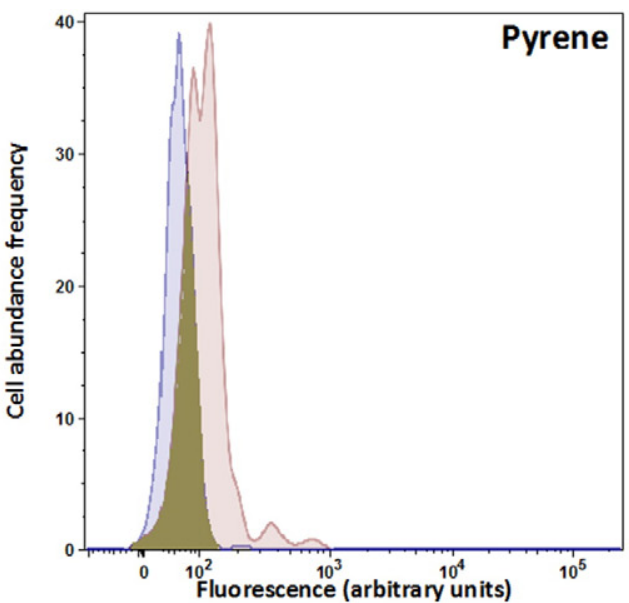

$375 \mathrm{~nm}$

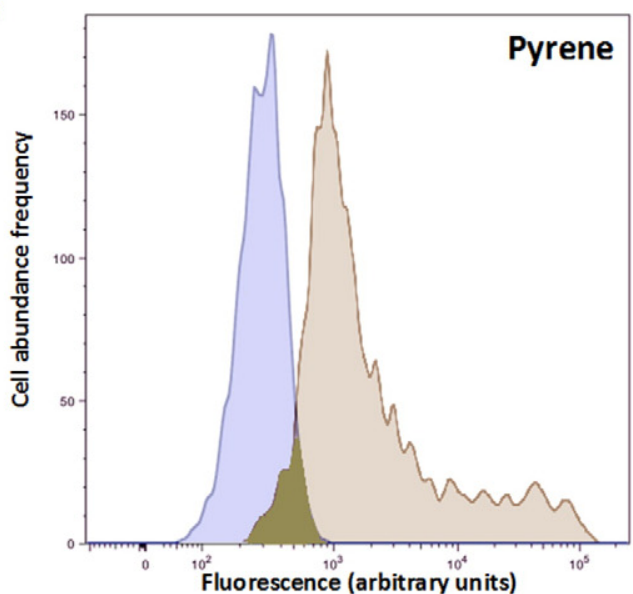

$355 \mathrm{~nm}$

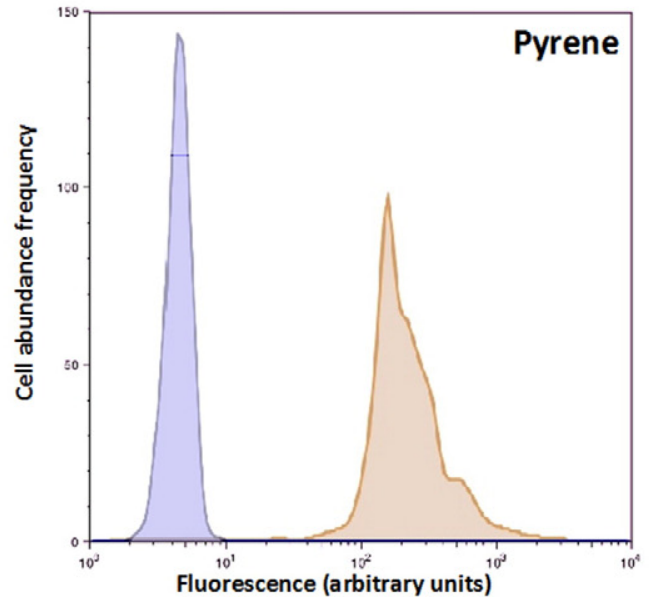

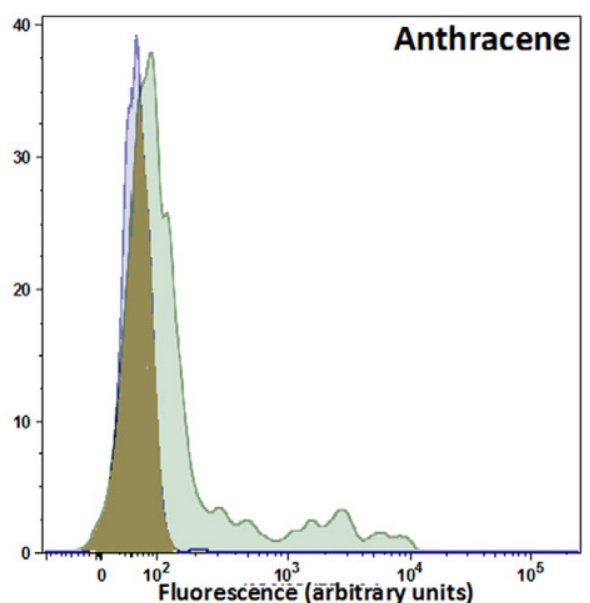
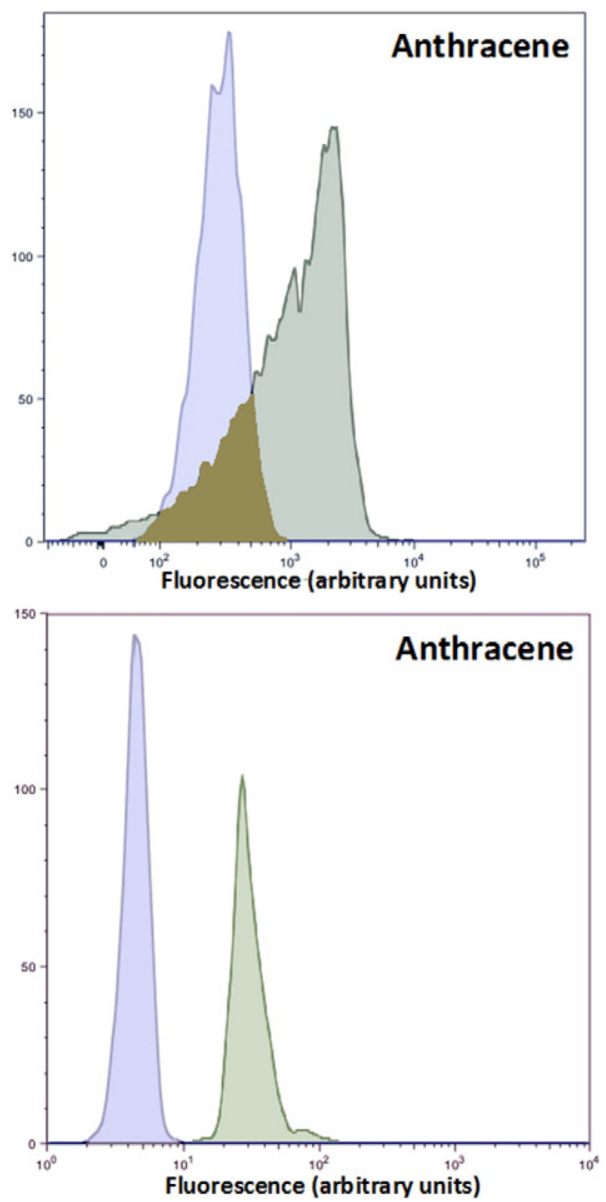

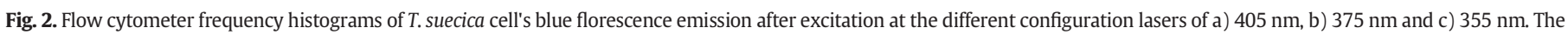

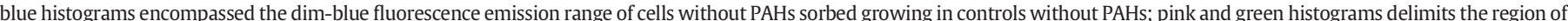

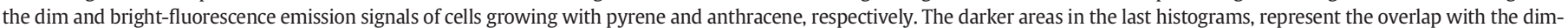

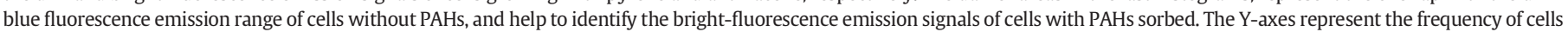
and the X-axes represent the intensity of cell blue fluorescence signals (arbitrary units).

$3 c$ and d). This is consistent with the rapid kinetics of PAHs surface accumulation described by Fan and Reinfelder (2003) in diatoms (1020 min after pollutant exposure). Other studies have shown that, in addition to rapid membrane accumulation or organic pollutants, the incorporation into cell by diffusion process is much slower (Swackhamer and Skoglund, 1993; Wallberg et al., 2001; Wallberg and Andersson, 1999). In our study, the proportion of cells with bright PAHs staining increased with longer exposure time (Fig. $3 c$ and $d ; p<0.001$ ). However, at low dosages the percentage of PAHs-bright cells decreased with increasing cell abundance (Fig. 4), suggesting clearance of sorbed pollutants. This corresponds to the previously described dilution of PAHs with cell growth (Fan and Reinfelder, 2003; Skoglund et al., 1996), which corresponds with a decrease of PAHs concentration at which cells are exposed, as a result of the increase in the number of cells present in the medium with a constant concentration of PAHs. Alternatively, intracellular incorporation by diffusion may reduce the quantity of membrane accumulation at the cell surface (Skoglund et al., 1996), but would still contribute to cell MFI by flow cytometry. When samples were observed 
Table 2

Percentages of $T$. suecica cells showing bright-blue fluorescence emission (indicative of PAHs sorbed) identified by flow cytometers configured with different excitation lasers of $405 \mathrm{~nm}, 375 \mathrm{~nm}$ and $355 \mathrm{~nm}$ wavelengths. Cells were exposed to different dosages of pyrene and anthracene.

\begin{tabular}{|c|c|c|c|c|c|c|}
\hline & \multicolumn{3}{|c|}{ Pyrene $\left(500 \mu \mathrm{g} \mathrm{L}^{-1}\right)$} & \multicolumn{3}{|c|}{ Anthracene $\left(300 \mu \mathrm{g} \mathrm{L}^{-1}\right)$} \\
\hline & $405 \mathrm{~nm}$ & $375 \mathrm{~nm}$ & $355 \mathrm{~nm}$ & $405 \mathrm{~nm}$ & $375 \mathrm{~nm}$ & $355 \mathrm{~nm}$ \\
\hline Mean & 95.09 & 94.43 & 91.76 & 62.31 & 74.88 & $20.80^{*}$ \\
\hline \multirow[t]{3}{*}{ SE } & 1.77 & 2.10 & 2.19 & 11.31 & 7.16 & 6.48 \\
\hline & \multicolumn{3}{|c|}{ Pyrene (25 $\left.\mu \mathrm{g} \mathrm{L}^{-1}\right)$} & \multicolumn{3}{|c|}{ Anthracene $\left(10 \mu \mathrm{g} \mathrm{L}^{-1}\right)$} \\
\hline & $405 \mathrm{~nm}$ & $375 \mathrm{~nm}$ & $355 \mathrm{~nm}$ & $405 \mathrm{~nm}$ & $375 \mathrm{~nm}$ & $355 \mathrm{~nm}$ \\
\hline Mean & 37.28 & $87.80^{*}$ & 49.35 & 20.57 & 27.08 & 26.07 \\
\hline SE & 10.66 & 7.01 & 14.55 & 6.38 & 7.18 & 7.29 \\
\hline
\end{tabular}

*The asterisks indicate significant differences ( $t$-test Anthracene laser $555 \mathrm{~nm}$ : laser $375 \mathrm{~nm} \mathrm{t}=54, \mathrm{df}=10, p<0.0005$; laser $405 \mathrm{~nm} \mathrm{t}=41, \mathrm{df}=10, p<0.005$. $t$-test pyrene laser $375 \mathrm{~nm}$ : laser $355 \mathrm{nmt}=39, \mathrm{df}=10, p<0.05$; laser $405 \mathrm{nmt}=49$, df $=10, p<0.01$ ).

by epifluorescence microscopy, blue fluorescence of $D$. Salina treated with PAHs, was not co-localized with any cellular structure. At high dosages of PAHs, most cells of Tetraselmis suecica, analyzed by flow cytometry, showed PAHs fluorescence, increasing the fluorescence with duration of PAHs treatment (Fig. 3c and d). These findings correspond with previous studies, showing that the exposure time, the pollutant dosages and cell growth are mechanisms that influence the accumulation of organic pollutants in phytoplankton organisms. The lipidic composition and the chemicals hydrophobicity were also identified as relevant mechanisms contributing to their accumulation in phytoplankton, that
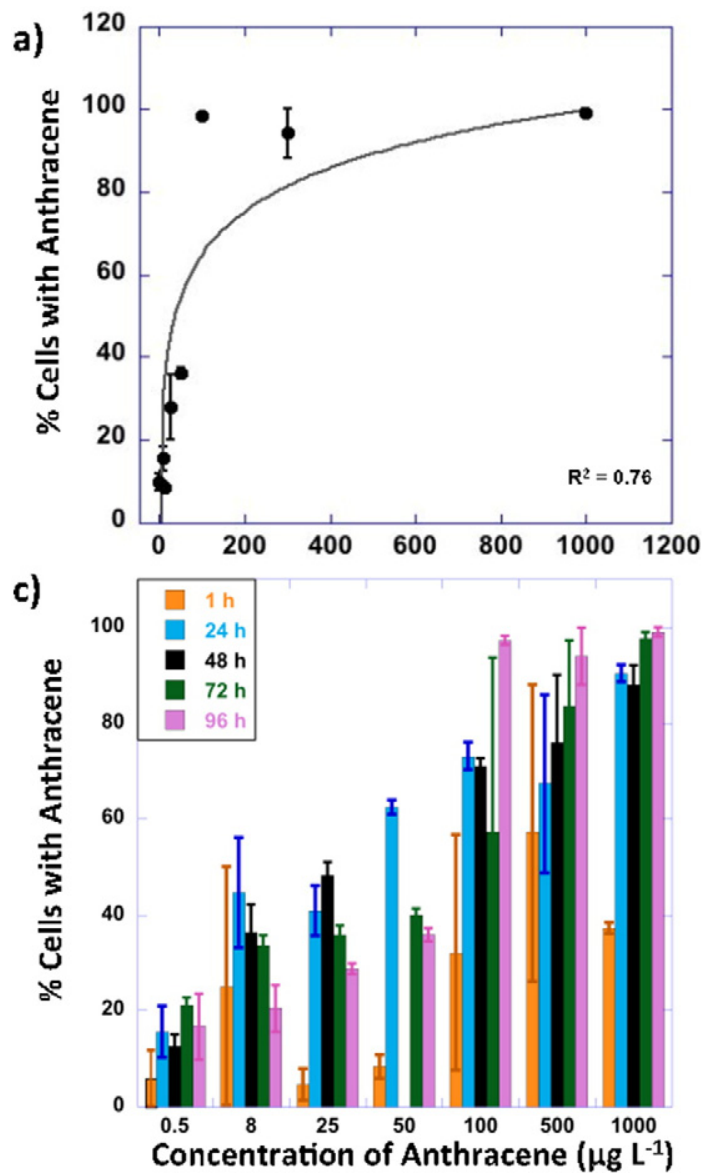

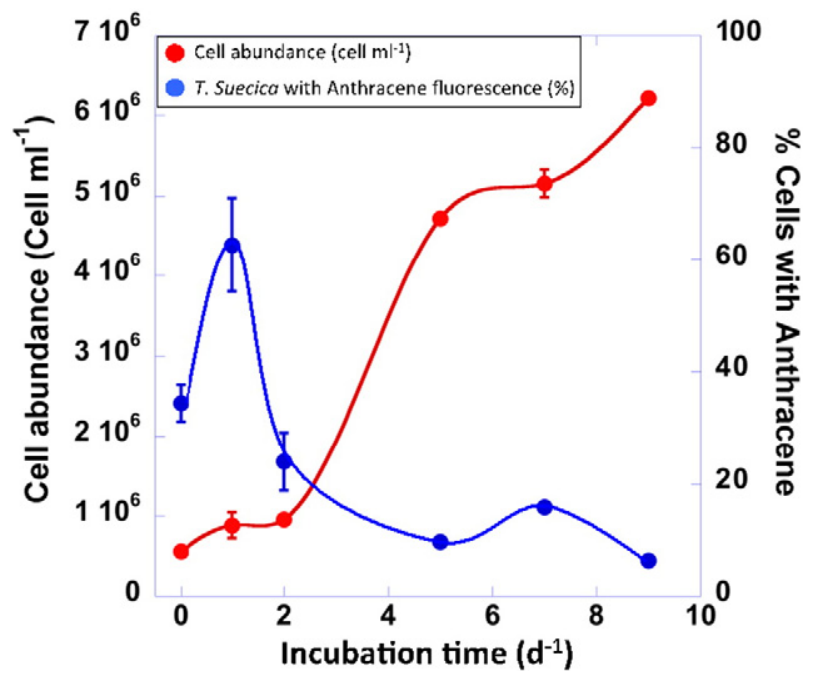

Fig. 4. Changes in the cell abundance (cell $\mathrm{mL}^{-1}$ ) (red dots), and in the percentage of anthracene bright-blue fluorescent $T$. suecica cells (blue dots) during the incubation time (hours) with $1.5 \mu \mathrm{g} \mathrm{L}{ }^{-1}$ anthracene. The error bars represent the SE values.

must help to explain the differences detected among species and chemicals (Koelmans, 2014; Skoglund et al., 1996). The lipidic content and composition of phytoplankton varies with taxa, and is influenced
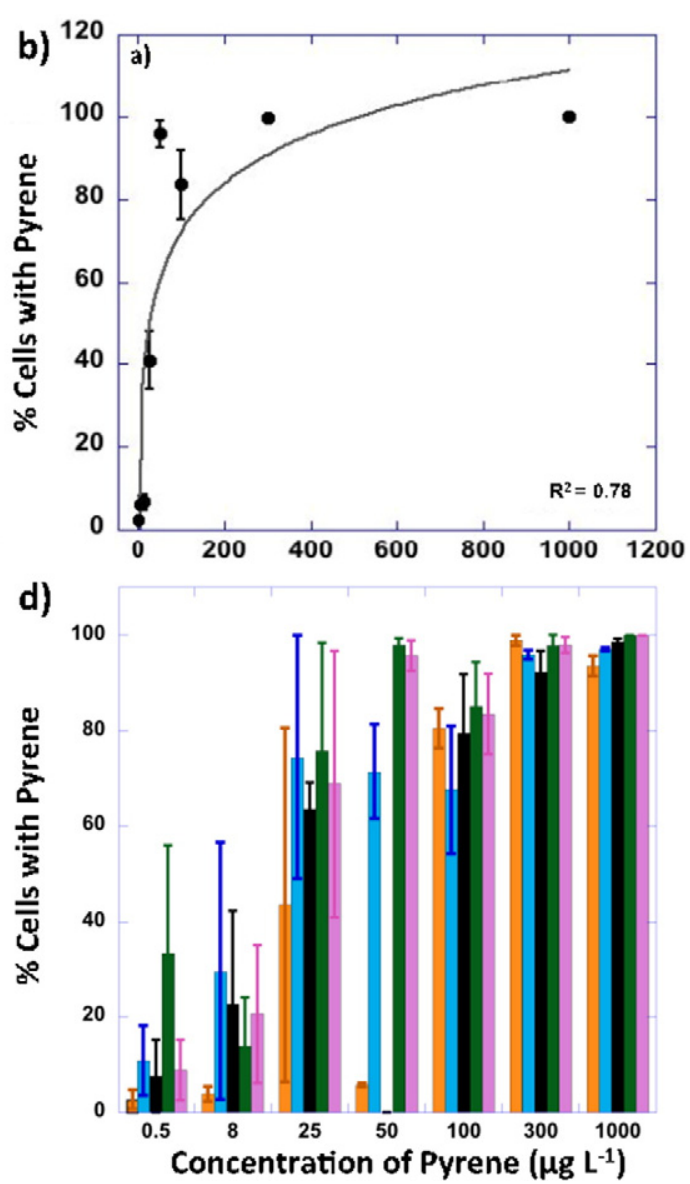

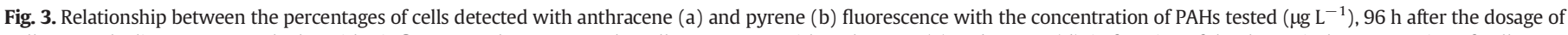

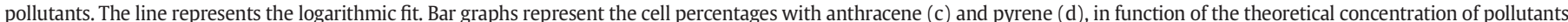

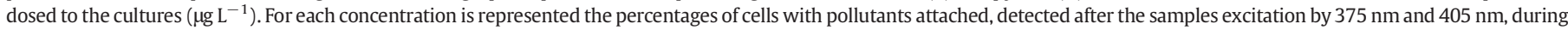

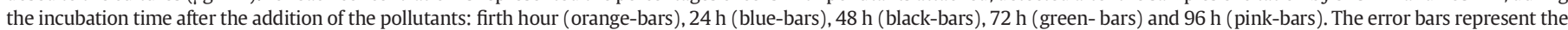
SE values. 

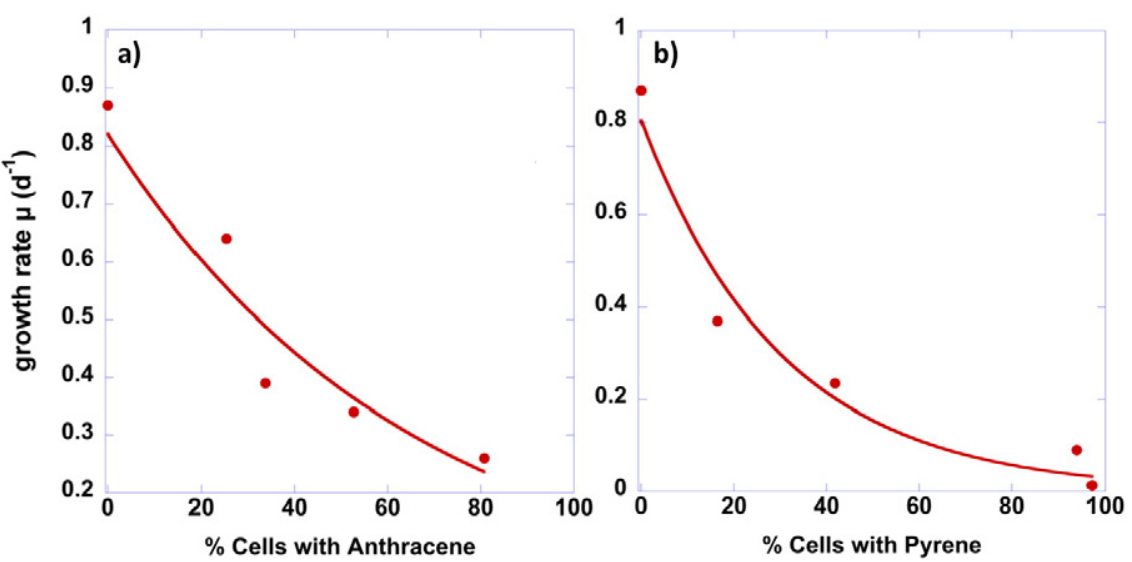

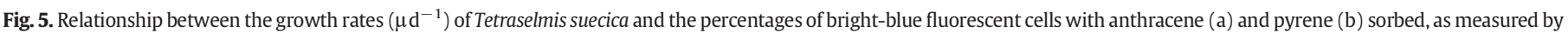
flow cytometry. (For interpretation of the references to color in this figure legend, the reader is referred to the web version of this article.)

by growth conditions as limitation by nutrients and solar radiation (Shifrin and Chisholm, 1981; Wang and Chai, 1994).

Limitations of our novel flow cytometry method include the inability to differentiate membrane associated and intracellular accumulations of PAHs over time. The dilution process observed at low PAHs dosages has been described previously in several studies (Fan and Reinfelder, 2003; Skoglund et al., 1996). Berrojalbiz et al. (2011) observed that the concentration of PAHs per cell decrease exponentially with the increase in biomass. Thus analysis by flow cytometry may only be appropriate in assessment of planktonic communities exposed to pollution from oil inputs during the first days of exposure, or in marine areas where the concentration of pollutants is high, like harbors.

Exposure of the cell cultures to the PAHs had a clear negative effect on growth. Growth decreased significantly as the percentage of PAHsbright cells increased for anthracene $(p<0.03)$ and pyrene $(p<0.04$; Fig. 5). Pyrene was between 2 and 20 times more effective at inhibiting growth than anthracene $(p<0.001$; Fig. 5$)$. This may reflect increased relative toxicity of pyrene, resulting from its highly aromatic structure (Millemann et al., 1984). These results demonstrate that accumulation of pollutants on cells, as demonstrated by flow cytometry, reduced the growth rate in culture. At 100\% PAHs-bright cells, the culture collapsed, with negative growth rate i.e. cell death. Previous studies have described the reduction of motility and absorption of nutrients and substances by exchange membrane as a result PAHs sorption to the cell membrane (Jiang et al., 2010; Skoglund et al., 1996). Once internalized, PAHs continue having negative effects on cell growth and viability (Jackson et al., 1989), decreasing protein synthesis and photosynthesis efficiency (Echeveste et al., 2011; Jiang et al., 2010).

\section{Conclusion}

In our study we have identified and quantified phytoplankton cells with PAHs (pyrene and anthracene) accumulated on cells by relatively simple and accessible flow cytometric techniques, using a configuration of UV lasers and optical filters in addition to the standard $488 \mathrm{~nm}$ laser necessary to identify phytoplanktonic organisms. We applied the technique in an ecotoxicological study under laboratory conditions, demonstrating growth inhibition with the accumulation of PAHs to cells in culture. In addition to applications in similar ecotoxicology research with cultured cells, flow cytometry allows the rapid counting of plankton abundance and identification of subpopulations within communities and is routinely used in oceanographic studies. Traditional techniques to measure PAHs in biological matrixes require the chemical analysis (Berrojalbiz et al., 2009; Skoglund et al., 1996) that in the case of marine phytoplankton implies a previous concentration of samples. The flow cytometer technique described here could allow the cell-bycell analysis of a variety of properties simultaneously within minutes of sampling, such as photosynthetic pigments auto-fluorescence and cell size (Marie et al., 2000), cell viability (Agustí and Sánchez, 2002), DNA content (Marie et al., 1997), rRNA hybridization (Simon et al., 1995), and so on. Cell-by-cell analysis may be more relevant than the averaged concentration from the whole populations achieved by traditional techniques. Further development of our seminal flow cytometry technique may extend applicability for a variety of approaches improving capabilities to study PAHs toxicity in other planktonic organisms at their natural environment affected by pollution. It is important to monitor marine oil pollution as PAHs compounds have important and welldescribed negative effects in the marine community (Echeveste et al., 2010; González et al., 2009; Jiang et al., 2010; Skoglund et al., 1996).

\section{Author contributions}

The manuscript was written through contributions of all authors. All authors have given approval to the final version of the manuscript. The three authors contributed equally.

\section{Acknowledgment}

This research was supported by the Spanish Ministry of Economy and Competitiveness by the project StressX (CTM2012-32603) and the Australian Research Council's Discovery Projects (project number DP140100825). M.I. Cerezo acknowledges a pre-doctoral fellow-ship from the JAE program (JAEPre121) of the Consejo Superior de Investigaciones Cientificas (CSIC). The authors acknowledge the facilities, and the scientific and technical assistance of the Australian Microscopy \& Microanalysis Research Facility at the Centre for Microscopy, Characterization \& Analysis, the University of Western Australia, a facility funded by the University, State and Commonwealth Governments.

\section{Appendix A. Supplementary data}

Supplementary data to this article can be found online at http://dx. doi.org/10.1016/j.marpolbul.2017.02.006.

\section{References}

Agustí, S., Sánchez, C.M., 2002. Cell viability in natural phytoplankton communities quantified by a membrane permeability probe. Limnol. Oceanogr. 47, 818-828.

Almeda, R., Bona, S., Foster, C.R., Buskey, E.J., 2014b. Dispersant Corexit 9500A and chemically dispersed crude oil decreases the growth rates of meroplanktonic barnacle nauplii (Amphibalanus improvisus) and tornaria larvae (Schizocardium sp.). Mar. Environ. Res. 99, 212-217.

Almeda, R., Connelly, T.L., Buskey, E.J., 2014c. Novel insight into the role of heterotrophic dinoflagellates in the fate of crude oil in the sea. Sci. Rep. 4, 7560. 
Almeda, R., Baca, S., Hyatt, C., Buskey, E.J., 2014a. Ingestion and sublethal effects of physically and chemically dispersed crude oil on marine planktonic copepods. Ecotoxicology 23, 988-1003.

Basu, R.G., Chakraborty, I., Moulik, S.P., 2006. Pyrene absorption can be a convenient method for probing critical micellar concentration $(\mathrm{cmc})$ and indexing micellar polarity. J. Colloid Interface Sci. 294 (1), 248-254.

Berrojalbiz, N., Dachs, J., Ojeda, M.J., Valle, M.C., Castro-Jimenez, J., Wollgast, J., Ghiani, M., Hanke, G., Zaldivar, J.M., 2011. Biogeochemical and physical controls on concentrations of polycyclic aromatic hydrocarbons in water and plankton of the Mediterranean and Black Seas. Glob. Biogeochem. Cycles 25.

Berrojalbiz, N., Lacorte, S., Calbet, A., Saiz, E., Barata, C., Dachs, J., 2009. Accumulation and cycling of polycyclic aromatic hydrocarbons in zooplankton. Environ. Sci. Technol. 43 (7), 2295-2301.

Chisholm, W., Olson, R.J., Zettler, E.R., Goericke, R., Waterbury, J.B., Welschmeyer, N.A., 1998. A novel free-living prochlorophyte abundant in the oceanic euphotic zone. Nature $334,340-343$.

Czechowska, K., van der Meer, J.R., 2011. A flow cytometry based oligotrophic pollutant exposure test to detect bacterial growth inhibition and cell injury. Environ. Sci. Technol. 45 (13), 5820-5827.

Dachs, J., Lohmann, R., Ockenden, W.A., Mejanelle, L., Eisenreich, S.J., Jones, K.C., 2002. Oceanic biogeochemical controls on global dynamics of persistent organic pollutants. Environ. Sci. Technol. 36 (20), 4229-4237.

Dartnell, L.R., Patel, M.R., Storrie-Lombardi, M.C., Ward, J.M., Muller, J.P., 2012. Experimental determination of photostability and fluorescence-based detection of PAHs on the Martian surface. Meteorit. Planet. Sci. 47 (5), 806-819.

Echeveste, P., Agustí, S., Dachs, J., 2011. Cell size dependence of additive versus synergetic effects of UV radiation and PAHs on oceanic phytoplankton. Environ. Pollut. 159 (5), 1307-1316.

Echeveste, P., Agustí, S., Dachs, J., 2010. Cell size dependent toxicity thresholds of polycyclic aromatic hydrocarbons to natural and cultured phytoplankton populations. Environ. Pollut. 158 (1), 299-307.

Fan, C.W., Reinfelder, J.R., 2003. Phenanthrene accumulation kinetics in marine diatoms. Environ. Sci. Technol. 37 (15), 3405-3412.

Fordham, R.J., Dubois, J.J., Glaude, P.G.J.M., Ligthart, J.A.M., 1985. In: Karcher, W. (Ed.), Spectral Atlas of Polycyclic Aromatic Compounds. Reidel, Dordrecht.

Gelboin, H.V., 1980. Benzo[a]pyrene metabolism, activation, and carcinogenesis: role and regulation of mixed-function oxidases and related enzymes. Physiol. Rev. 60 (4), 1107-1167.

Godfrey, W.L., Hill, D.M., Kilgore, J.A., Buller, G.M., Bradford, J.A., Gray, D.R., Clements, I., Oakleaf, K., Salisbury, J.J., Ignatius, M.J., Janes, M.S., 2005. Complementarity of flow cytometry and fluorescence microscopy. Microsc. Microanal. 11 (S02), 246-247.

González, J., Figueiras, F.G., Aranguren-Gassis, M., Crespo, B.G., Fernández, E., Morán, X.A.G., Nieto-Cid, M., 2009. Effect of a simulated oil spill on natural assemblages of marine phytoplankton enclosed in microcosms. Estuar. Coast. Shelf Sci. 83 (3), 265-276.

Habibi, M.H., Hadjmohammadi, M.R., 2008. Determination of some polycyclic aromatic hydrocarbons in the caspian seawater by HPLC following preconcentration with solid-phase extraction. Iran. J. Chem. Chem. Eng. 27 (4) (Research Note).

Hjorth, M., Vester, J., Henriksen, P., Forbes, V., Dahllöf, I., 2007. Functional and structural responses of marine plankton food web to pyrene contamination. Mar. Ecol. Prog. Ser. 338, 21-31.

Jackson, J.B., Cubit, J.D., Keller, B.D., Batista, V., Burns, K., Caffey, H.M., Caldwell, R.L., Garrity, S.D., Getter, C.D., Gonzalez, C., Guzman, H.M., Kaufmann, K.W., Knap, H., Levings, S.C., Marshall, M.J., Steger, R., Thompson, R.C., Wil, E., 1989. Ecological effects of a major oil spill on Panamanian coastal marine communities. Science 243 (4887), 37-44.

Jiang, Z., Huang, Y., Xu, X., Liao, Y., Shou, L., Liu, J., Chen, Q., Zeng, J., 2010. Advance in the toxic effects of petroleum water accommodated fraction on marine plankton. Acta Ecol. Sin. 30 (1), 8-15.

Koelmans, A.A., 2014. Limited reversibility of bioconcentration of hydrophobic organic chemicals in phytoplankton. Environ. Sci. Technol. 48 (13), 7341-7348.
Lehr, R.E., Jerina, D.M., 1977. Metabolic activations of polycyclic hydrocarbons. Arch. Toxicol. 39 (1-2), 1-6.

Lehto, K.M., Vuorimaa, E., Lemmetyinen, H., 2000. Photolysis of polycyclic aromatic hydrocarbons (PAHs) in dilute aqueous solutions detected by fluorescence. J. Photochem. Photobiol., A 136 (1), 53-60.

Marie, D., Partensky, F., Jacquet, S., Vaulot, D., 1997. Enumeration and cell cycle analysis of natural populations of marine picoplankton by flow cytometry using the nucleic acid stain SYBR Green I. Appl. Environ. Microbiol. 63, 186e193.

Vaulot, D., 2000. Flow cytometry analysis of marine picoplankton. In: Marie, D., Partensky, F., Simon, N., Guillou, L., Diamond, R.A., DeMaggio, S. (Eds.), Living Colors: Protocols in Flow Cytometry and Cell Sorting. Springer-Verlag, Berlin, p. 422.

McGrath, T.E., Wooten, J.B., Geoffrey Chan, W., Hajaligol, M.R., 2007. Formation of polycyclic aromatic hydrocarbon from tobacco: the link between the low temperature residual solid (char) and PAH formation. Food Chem. Toxicol. 45 (6), 1039-1050.

Meador, J.P., Stein, J.E., Reichert, W.L., Varanasi, U., 1995. Bioaccumulation of polycyclic aromatic hydrocarbons by marine organisms. Reviews of Environmental Contamination and Toxicology. Springer, New York, p. 79.

Millemann, R.E., Birge, W.J., Black, J.A., Cushman, R.M., Daniels, K.L., Franco, P.J., Giddings, J.M., McCarthy, J.F., Stewart, A.J., 1984. Comparative acute toxicity of aquatic organisms of components of coal-derived synthetic fuels. Trans. Am. Fish. Soc. 113, 74-85.

Muratori, M., Forti, G., Baldi, E., 2008. Comparing flow cytometry and fluorescence microscopy for analyzing human sperm DNA fragmentation by TUNEL labeling. Cytometry A 73 (9), 785-787.

Nagata, S., Kondo, G., 1977. Photo-oxidation of crude oils. International Oil Spill Conference Proceedings: March. 1, pp. 617-620.

Neff, J.M., 1979. Polycyclic aromatic hydrocarbons in the aquatic environment. Sources, Fate, and Biological Effects. Applied Sciences, London.

Neff, J.M., 1985. Polycyclic aromatic hydrocarbons. In: Rand, G.M., Petrocelli, S.R. (Eds.), Fundamentals of Aquatic Toxicology. Taylor \& Francis, Bristol, p. 416.

Roper, M.M., 2006. Potential for remediation of water repellent soils by inoculation with wax-degrading bacteria in southwestern Australia. Biol. Bratis 61 (Suppl. 19) S358-S362.

Shapiro, H.M., 2005. Practical Flow Cytometry. John Wiley \& Sons.

Shifrin, N.S., Chisholm, S.W., 1981. Phytoplankton lipids: interspecific differences and effets of nitrate, silicate and light-dark cycles. J. Phycol. 17 (4), 374-384.

Simon, N., LeBot, N., Marie, D., Partensky, F., Vaulot, D., 1995. Fluorescent in situ hybridization with rRNA-targeted oligonucleotide probes to identify small phytoplankton by flow cytometry. Appl. Environ. Microbiol. 61 (7), 2506-2513.

Singh, A.K., Gaur, J.P., 1988. Effect of Assam crude on photosynthesis and associated electron transport system in Anabaena doliolum. Bull. Environ. Contam. Toxicol. 41 (4), 776-780.

Skoglund, R.S., Stange, K., Swackhamer, D.L., 1996. A kinetics model for predicting the accumulation of PCBs in phytoplankton. Environ. Sci. Technol. 30 (7), 2113-2120.

Suzuki, K., Kobayashi, A., Kaneko, S., Takehira, K., Yoshihara, T., Ishida, H., Shiina, Y., Oishic, S., Tobita, S., 2009. Reevaluation of absolute luminescence quantum yields of standard solutions using a spectrometer with an integrating sphere and a back-thinned CCD detector. Phys. Chem. Chem. Phys. 11 (42), 9850-9860.

Swackhamer, D.L., Skoglund, R.S., 1993. Bioaccumulation of PCBs by algae: kinetics versus equilibrium. Environ. Toxicol. Chem. 12 (5), 831-838.

Wallberg, P., Andersson, A., 1999. Determination of adsorbed and absorbed polychlorinated biphenyls (PCBs) in seawater microorganisms. Mar. Chem. 64 (4), 287-299.

Wallberg, P., Jonsson, P.R., Andersson, A., 2001. Trophic transfer and passive uptake of a polychlorinated biphenyl in experimental marine microbial communities. Environ. Toxicol. Chem. 20 (10), 2158-2164.

Wang, K.S., Chai, T., 1994. Reduction in omega-3 fatty acids by UV-B irradiation in microalgae. Phycology 6, 415-422.

Yentsch, C.S., Yentsch, C.M., 1979. Fluorescence spectral signatures: the characterization of phytoplankton populations by the use of excitation and emission spectra [Algae, diatoms]. J. Mar. Res. (USA). 